УДК 658

\title{
ПРОДЮСУВАННЯ ЯК СТРАТЕГІЧНИЙ НАПРЯМОК РОЗВИТКУ СУЧАСНОГО УКРАЇНСЬКОГО РЕПЕРТУАРНОГО ТЕАТРУ
}

\author{
Коваль І.М., директор (Харківський академічний театр музичної комедії), \\ здобувач
}

Несен Д.А., студентка магістратури, Сєріков А.В., к.фіз.-мат.н., професор (ХНУБА)

Статтю присвячено проблемі пошуку иляхів розбудови продюсування у сучасному українському репертуарному театрі, як одного із стратегічних напрямів його подальшого виживання та розвитку. Адекватно вибудоване продюсування може розв'язати протиріччя між статусною неприбутковістю репертуарних театрів, підтриманою бюджетним фінансуванням, та ринковим устроєм середовим життєдіяльності. Практична реалізація може відбутися через створення продюсерського иентру під дахом репертуарного театру. Такий центр для театру може стати творчим майданчиком, на якому будуть проходити випробування спектаклі у малобюджетному форматі.

Ключові слова: сучасний украйнський репертуарний театр, продюсування, продюсерський центр, прожект-менеджмент, причинно-наслідковий аналіз та синтез.

\section{ПРОДЮСИРОВАНИЕ КАК СТРАТЕГІЧЕСКОЕ НАПРАВЛЕНИЕ РАЗВИТИЯ СОВРЕМЕННОГО УКРАИНСКОГО РЕПЕРТУАРНОГО ТЕАТРА}

\section{Коваль И.Н., директор (Харьковский академический театр музыкальной комедии), соискатель,}

Несен Д.А., студентка магистратуры, Сериков А.В., к.физ.-мат.н., профессор (ХНУСА)

Статья посвящена проблеме поиска путей развития продюсирования в современном украинском репертуарном театре, как одного из стратегических направлений его дальнейшего выживания и развития. Адекватно построенное продюсирование может разрешить противоречия между статусной неприбыльностью репертуарных театров, поддержанной бюджетным финансированием, и рыночным укладом сред жизнедеятельности. Практическая реализация может произойти через создание продюсерского центра под крымей репертуарного театра. Такой чентр для театра может стать творческой площуадкой, на которой будут проходить испьтания спектакли в малобюджетном формате.

Ключевые слова: современный украинский репертуарный театр, продюсирование, продюсерский центр, прожект-менеджмент, причинноследственный анализ и синтез. 


\title{
PRODUCTION AS STRATEGIC DIRECTION OF THE DEVELOPMENT OF THE MODERN UKRAINIAN REPERTOIRE THEATER
}

\author{
Koval I.N., director (Kharkiv Academic Theater of musical comedy), aspirant, \\ Nesen D.A., a master student, \\ Serikov A.V., candidate physico-mathematical of sciences, professor \\ (KHNUCA)
}

The article is devoted to the problem of finding ways how to develop production in the modern Ukrainian repertoire theater, as one of the strategic directions of its further survival and development. Adequately constructed production can resolve the contradictions between the status unprofitableness of repertory theaters, supported by budgetary financing, and the market way of living environments. Practical implementation can be occured through the creation of a production center under the roof of the repertory theater. They will be called upon to increase the effectiveness of the newly created creative and production system. Performance indicators should be indicators of productivity, productivity and resource intensity Such symbiosis can be regarded as an independent systemic formation with new emergent properties. The theater may have an additional creative platform, on which new performances will be "rolled out" in a low-budget format. Passed such tests, stage works can then be developed as a full-format production. At the initial stage, the producer center can be viewed as a start-up, because today there are no regulatory rules for the coexistence of a nonprofit organization represented by the repertory theater and the business education contained in its internal environment. It is obvious that at the initial stage the leading role in the "repertory theater / producer center" system should be assigned to the management of the theater, which, in order to maintain the image of the theater, should show reasonable conservatism. The producer center in this case is given the role of "troublemaker". With the advent of experience, the production center can be transformed into a structure typical for design organizations. In this case, all its activities will be further regulated by the international standard ISO 21500:2012 "Guidance on Project Managment". As you know, it is applicable to any projects in any organization. There is hope for its successful use in the "repertory theater / producer center" system.

Key words: modern Ukrainian repertoire theater, production, production center, project management, cause-effect analysis and synthesis

Постановка проблеми. Виживання i подальший розвиток - це найгостріша проблема для будь-якого сучасного українського репертуарного театру. За Законом [1] (який є рамковим, бо не дає відповіді на всі виникаючі питання) репертуарні театри $€$ неприбутковими організаціями i існують за бюджетні кошти [1, ст. 14]. Останні невпинно скорочуються і знецінюються в умовах ринкових відносин, притаманних сучасній Україні.

Свідченням цього твердження може виступати динаміка бюджетування
Харківського академічного театру музичної комедії (ХАТМК), яку надано на рисунку 1.

В межах виконаного SWOT-аналізу для ХАТМК було виявлено наступні загрози, які актуальні для будь-якого сучасного українського репертуарного театру, а саме [2, С. 200]: (1) зростання дефіциту бюджету країни та регіону, що може призупинити бюджетне утримання театрів (2) підвищення темпів інфляції, (3) економічна нестабільність, (4) політична нестабільність, (5) зростання податкових ставок, (6) Зниження 
платоспроможності глядачів, (7) низький попит 3 боку глядачів на театральні послуги, (8) значна мінливість потреб 3 боку глядачів, (9) високий рівень конкурентоздатності інших театрів i закладів культури, (10) зміна суспільних цінностей, (11) низька соціальна свідомість населення.

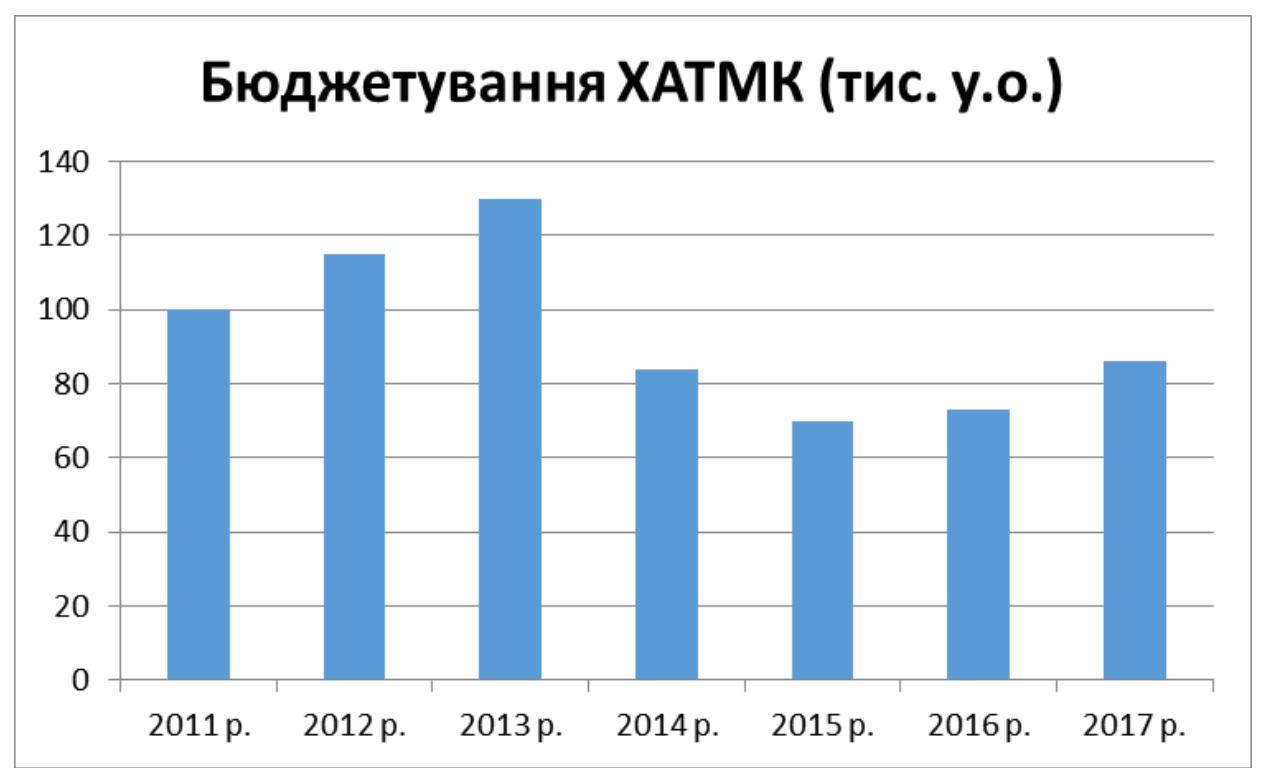

Рис. 1. Динаміка бюджетування ХАТМК у 2011 - 2017 роках [2, С. 192]

За перелічених умов вирішення озвученої проблеми виживання та розвитку потребує пошуку нових стратегічних підходів до організації діяльності та управління цими театрами, що бачиться достатньо актуальним. Можливості містяться в самому Законі [1], який дозволяє театрам заробляти кошти за рахунок різних видів комерційної діяльності. Стратегічно найбільш перспективним виявляється продюсування [1, ст. 15], яке використовується практично всіма закордонними неприбутковими театрами [3; 4].

На підтримку такої діяльності можна долучити можливості, що надаються Законом [5, ст. 4] щодо державно-приватного партнерства в сферах туризму, відпочинку, рекреації, культурі та спорті.

Аналіз останніх досліджень i публікацій. Публікацій вітчизняних дослідників, присвячених питанням продюсування в сучасних українських репертуарних театрах авторам даної статті невідомі. Серед закордонних праць доречно відзначити роботи [3; 4].
Грунтовний бестселер [3] відомого американського фахівця 3 теорії та практики управління театрами Стіва Ленглі на протязі майже чотирьох десятиліть не втрачає затребуваності. Але американська практика театрального продюсування не вміщається у «прокрустове ложе» українських умов господарювання. Майже «свіжа» монографія [4] присвячена аналізу історичної, теоретико-організаційної, соціальної діяльності некомерційних регіональних (постійних, репертуарних) театрів США із моменту їхнього виникнення до даного часу. Праця містить достатньо прикладів розвитку різноманітних театральних колективів. Але узагальнити досвід їхнього існування та втілити його в українську дійсність поки що не уявляється можливим.

Виділення невирішених частин загальної проблеми. 3 огляду на представлену інформацію можна стверджувати, що розробки теорії та практики продюсування у сучасному українському репертуарному театрі ще чекають свого часу та дослідників. 
Метою даної статті є попередній комерція [6, С. 559]-торгівля і пов'язані пошук шляхів для розбудови з нею справи. Тобто надалі необхідно буде продюсування у сучасному українському вирішувати проблему «вбудовування» в репертуарному театрі, який $\epsilon$ неприбутковою організацією, що працює за ринкових умов.

Виклад основного матеріалу дослідження. Великий тлумачний словник сучасної української мови надає наступні дефініції: (1) продюсер [6, С. 1152] - адміністративно-фінансовий організатор діяльності зі здійснення якогонебудь комерційного проекту (різних шоу, концертів, телепрограм, запису альбомів, дисків, відео кліпів і таке інше); (2) некомерційну організацію «генетично» протилежну комерційну структуру, що може породжувати внутрішньо обумовлені конфлікти у всіх середовищах репертуарного театру.

Модель діяльності театрального продюсера (див. рис. 2) можна побудувати за матеріалами публікації [7] Олександра Роднянського, який у 1995 році створив перший незалежний україномовний телеканал «1+1».

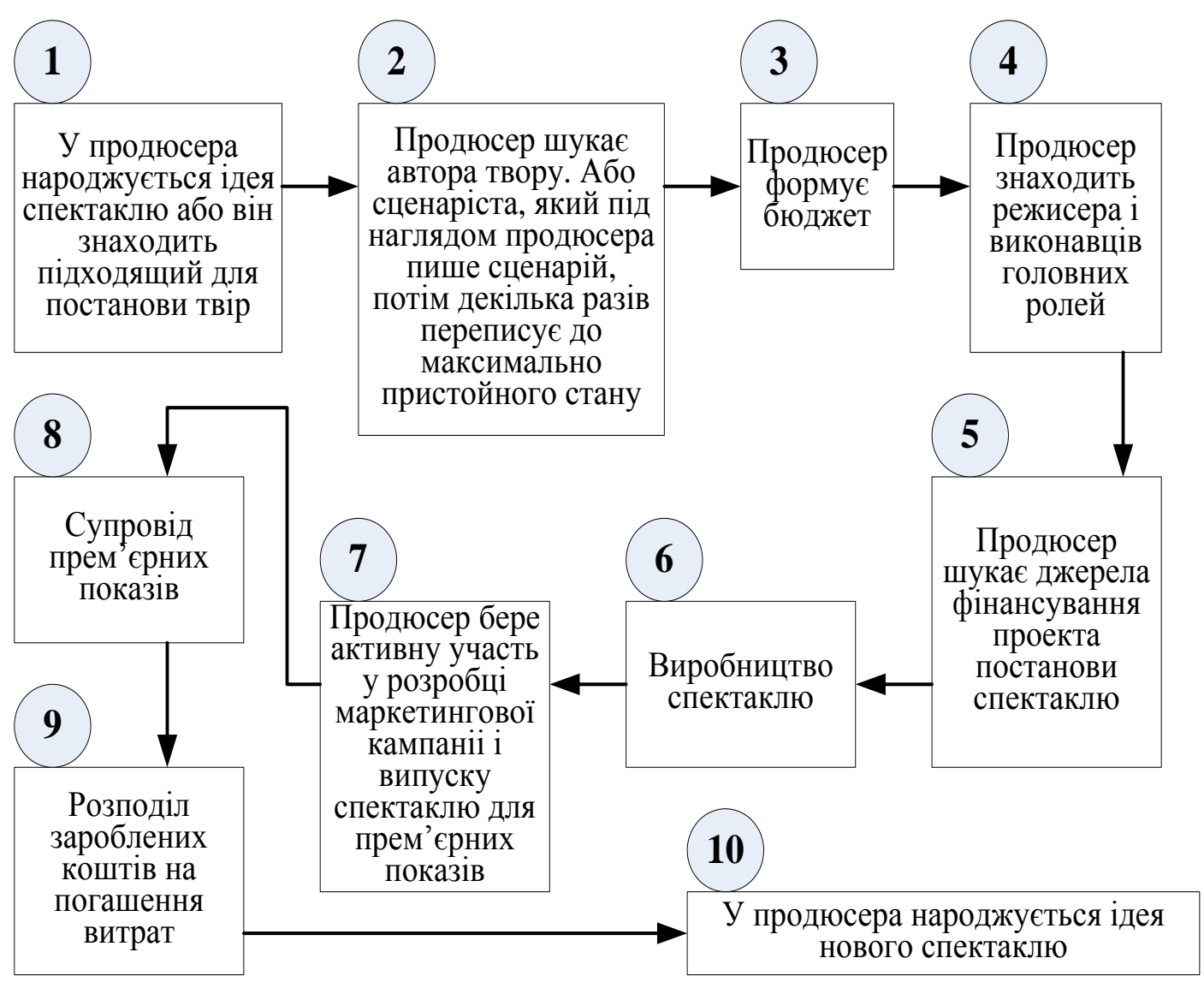

Рис. 2. Модель дій продюсера у репертуарному театрі (авторська розробка «за мотивами» роботи [7])

Уся діяльність продюсера має суто проектний характер. Керівники проектів розбивають цикли їхнього життя на етапи різними способами. Однак найбільш традиційною є розбивка проекту на п’ять великих етапи (див. рис. 3): ініціювання; (2) планування та розробка; (3) виконання та впровадження; (4) моніторинг та контроль; (5) завершення. Для виконання продюсерських 
проектів доцільно використовувати всі його уваги та відповідальності висвітлено теоретичні і практичні надбання того, що на рис. 4.

зветься прожект-менеджмен-том. Зони

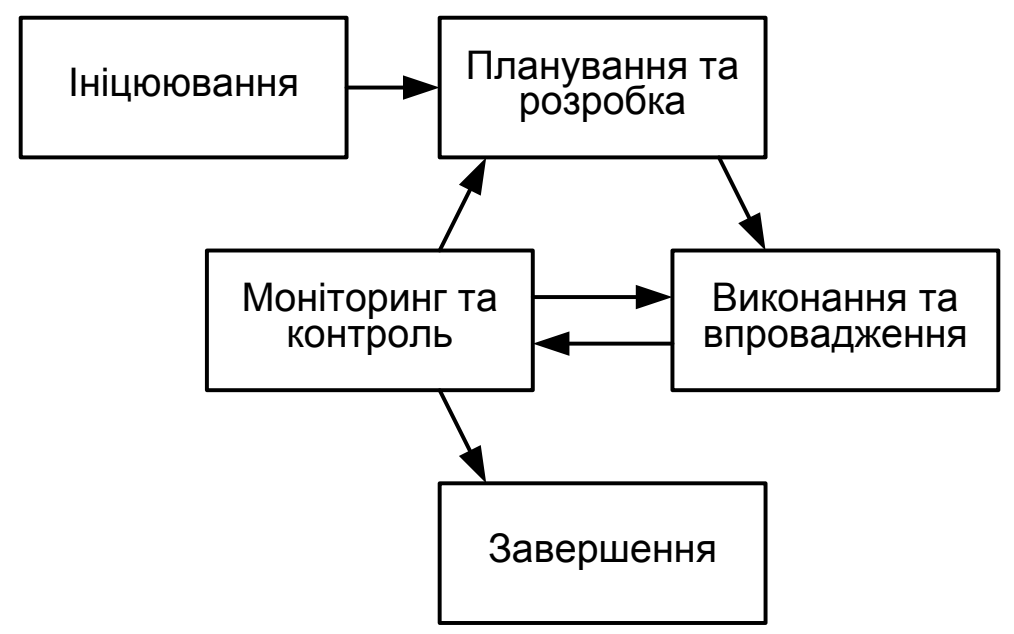

Pис. 3. Етапи проекту [8, C. 31]

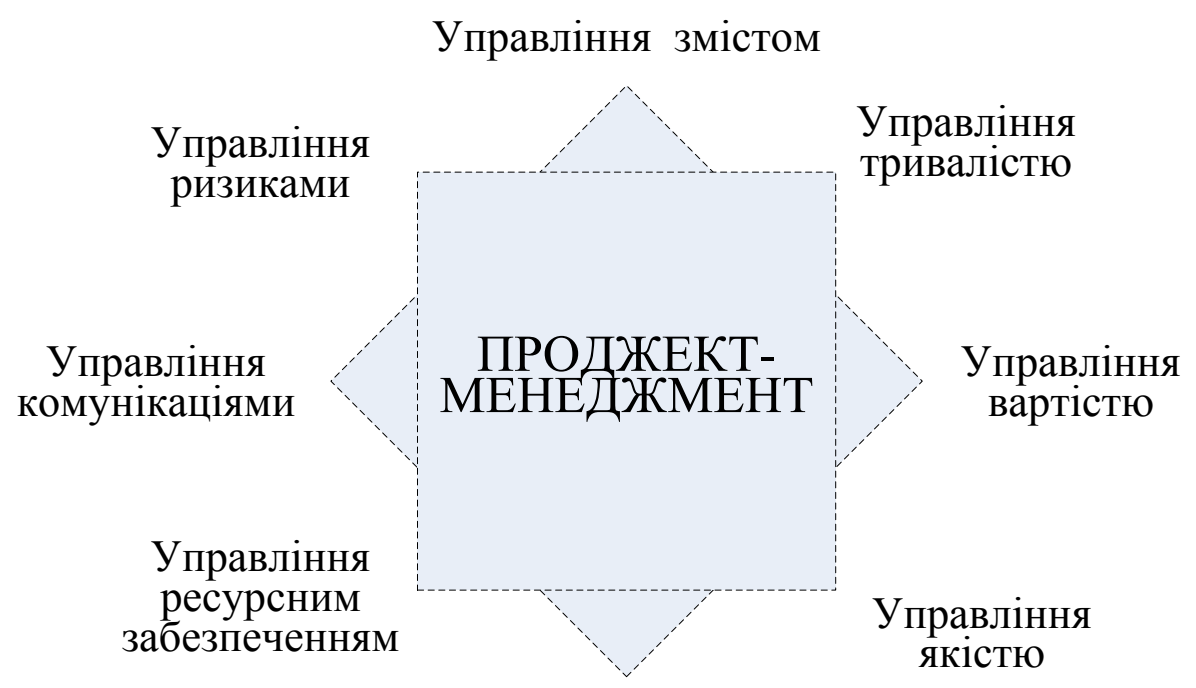

Управління персоналом

Рис. 4. Підсистеми управління театральним проектом [8, С. 39]

Щоб все відзначене на рис. 4 більш-менш грамотно відпрацьовувати, доцільно започаткувати при/в репертуарному театрі структурну одиницю 3 участю приватного капіталу під назвою «продюсерський центр».
Місце і очікувані результати такого центру у творчо-виробничому театральному процесі стають певною мірою зрозумілими із причиннонаслідкового аналізу заходів, що зображені на рисунку 5 та налаштовані на стратегію подальшого розвитку театру. 


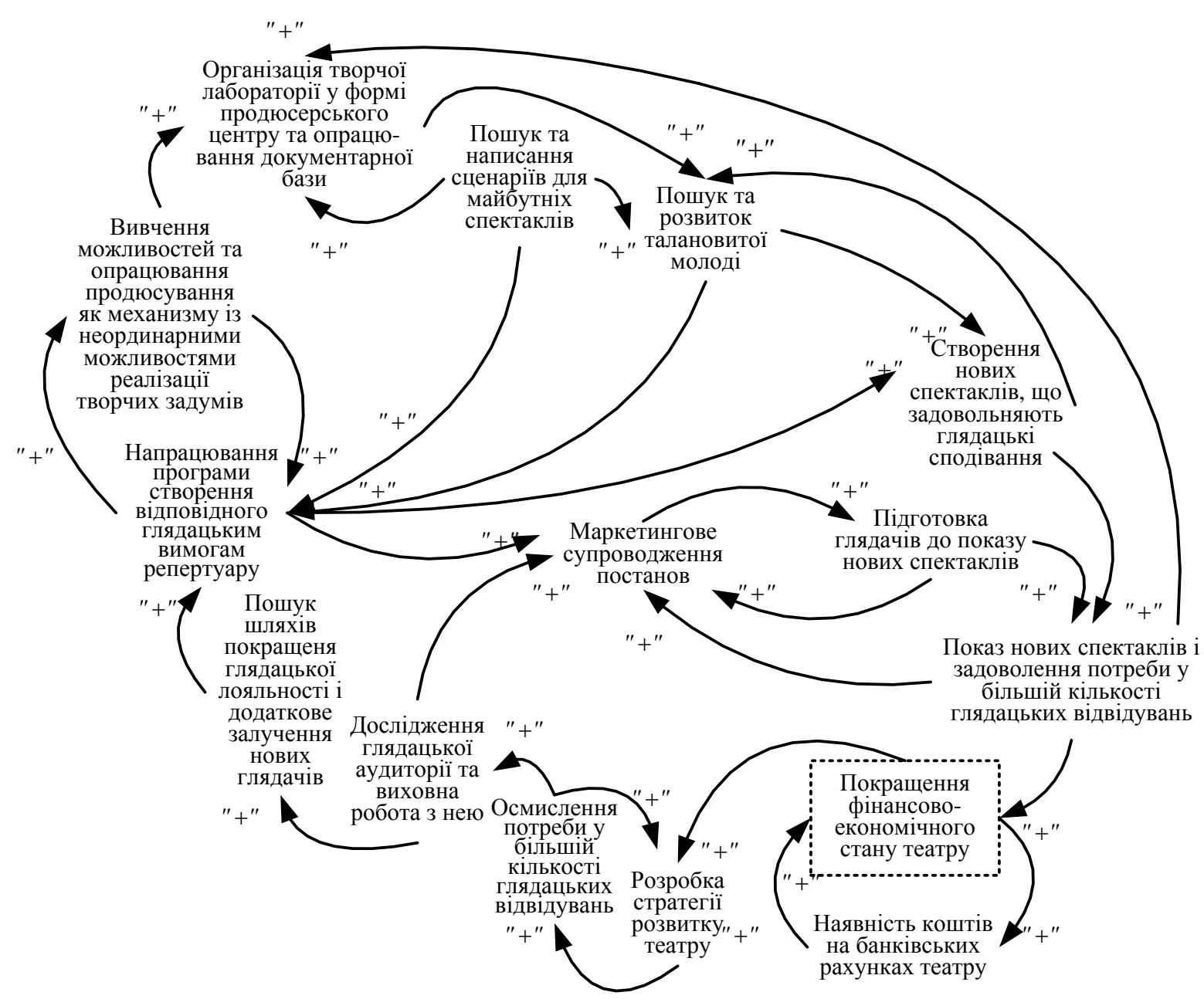

Рис. 5. Причинно-наслідковий аналіз та синтез заходів із стратегії розвитку сучасного українського репертуарного театру за рахунок продюсування (авторська розробка за методикою із роботи [10])

Тут фундаментальний принцип системного мислення, за яким складні проблеми краще всього описувати в термінах мереж взаємозв'язаних петель зворотного зв'язку [10, С. 57]. Петлі зворотного зв'язку $є$ складовою усіх діаграм циклічної причинності. Відомі два типи петель зворотного зв'язку : що посилює i що врівноважує. Необхідно звернути увагу на напрям стрілок, бо кожна з них вказує на причинно-наслідкові зв'язки. Щоб показати, що дві змінні рухаються в одному напрямі, на діаграмі поряд із стрілкою стоїть знак «+» (це позитивний, посилюючий зв'язок); рух в протилежних напрямах відзначається знаком «-» (це свідчення негативного, що врівноважує, зв'язку). Згідно із діаграмою на рис. 5, щоб покращити фінансово-економічний стан репертуарного театру у межах стратегії його розвитку можна пропонувати пошук шляхів підвищення глядацької лояльності до театру за рахунок створення та показу нових спектаклів, що згенерує потребу глядачів частіше відвідувати спектаклі театру [10]. Для забезпечення такої політики знадобиться ціла низка заходів, а came:

- осмислити потреби у більшій кількості глядацьких відвідувань;

$$
\text { досліджувати глядацьку }
$$

аудиторію та вести виховну роботу в ній [11]; 
- організувати творчу лабораторію, наприклад, у формі продюсерського центру;

\begin{tabular}{llr}
\multicolumn{1}{c}{-} & відпрацьовувати & програми \\
створення відпвідного & глядацьким \\
вимогам репертуару та & виховання \\
«артистів-зірок»; &
\end{tabular}

- займатися безперервно пошуком та написанням сценаріїв для майбутніх спектаклів, а також пошуком та розвитком талановитої молоді;

- створювати нові спектаклі, які відповідали б глядацьким очікуванням;

- доносити всю інформацію про новини широким колам майбутніх глядачів;

забезпечувати креативне маркетингове супроводження постанов $[12 ; 13]$;

- відпрацьовувати усі нормативні документи щодо створення та функціонування продюсерського центру, одним iз призначень якого $\epsilon$ акумулювання необхідного досвіду.

Останне продиктоване тим, що процеси створення та використання результатів творчості людини завжди пов'язані зі складностями, що обумовлені організаційно-економічними (умови та порядок створення, місце творчої діяльності, iï інвестування та подальша комерціалізація результатів тощо) та юриспруденто-технічними (оформлення, реєстрація, охорона тощо) обставинами. Тому, автори (творці) вимушені звертатися до продюсерів, що мають відповідні здібності, можливості, знання та уміння і надають послуги з організації творчого процесу створення творів, їх належної охорони та подальшої комерціалізації. Надання згаданих послуг повинне здійснюватися на підставі так званих продюсерських договорів (як за кордоном). Але чинне українське законодавство не передбачає даного виду договорів, їх істотних умов та форми. Тому, правовідносини між авторами, виконавцями та продюсерами можуть оформлятися лише договорами підряду, надання послуг та іншими, що в цілому суттєво знижує ефективність захисту прав та інтересів як продюсера, так і автора, виконавця та $\epsilon$ предметом неодноразових суперечок [14].

Уявляється вкрай доцільним вивчити практику регулювання взаємовідносин дійових осіб на театральних підмостках, наприклад, у США. Там взаємовідносини між учасниками творчо-виробничого процесу в неприбутковому театрі регулюються низкою спеціальних контрактів Асоціації Рівноправних Акторів (АРА). Серед них можна відзначити наступні контракти [15, C. 145]:

(1) для театрів-членів Ліги Постійних Театрів (п'ять категорій театрів: A; B+; B; C; D - категорія визначається середнім тижневим доходом за останні три роки, А - найвищий дохід, D - найнижчий);

(2) контракти позабродвейних театрів (позабродвейний контракт стосується постановок в районі Манхетена чи для будь-якого театру з місткістю залу до 499 місць);

(3) контракт театру юного глядача (ставлять спеціальний дитячий чи пристосований для дітей літературний матеріал не вище 8 ступеня (окрім Шекспірівських адаптацій) 3 тривалістю вистави не більше 1,5 години 3 антрактом);

(4) фондовий контракт (дозволяється використовувати у виставах непрофесіональних акторів (за контрактом AРА), що значно зменшує видатки театру, але не завжди призводить до бажаного результату);

(5) контракт зі спеціальними обмеженнями (для того, щоб мати справу 3 членами АРА, які обрали роботу без заробітної плати в позабродвейних театрах Нью-Йорку або в подібних театрах в інших містах, Асоціація виробила так звані «спеціальні обмеження»; це дозволяє продюсерам існувати за рахунок касових зборів, однак розмір глядацького залу має 
бути менше ста місць, а кількість виконавців обмежується двадцятьма; кількість непрофесіоналів у таких виставах не обмежується; їхні права захищає організація під назвою «Альянс Постійних Театрів» Нью- Йорк);

(6) контракт на студійні постановки (студійні майстерні, схвалені АРА та організовані $з$ метою розвитку вистави в можливу комерційну постановку, використовують акторів - тільки членів спілки; вони отримують меншу зарплату, студійні репетиції тривають 6-12 тижнів і можуть бути припинені не більше, ніж на два тижні для правок п’єс (сценаріїв);

(7) контракт для кабаре - театрів (кабаре-шоу можуть тривати не більше дев'яноста хвилин і повинні проходити в тій самій залі, де подаються їжа та напої; так само, як і у випадку зі «спеціальними обмеженнями», коли кабаре-шоу ставиться за стандартним контрактом, актори повинні бути забезпечені ролями згідно з їх амплуа, інакше їм сплачується спеціальна компенсація); контракт Професіональних Театрів (цей вид контрактів створений для театрів 3 місткістю залу до 350 місць, місце розташування яких знаходиться в містах, де немає

регіональних представництв АРА); план театру на 99 місць (план базується на використанні контракту для малих професіональних позабродвейних театрів $\mathrm{i}$ передбачає десять категорій зарплат, розмір яких залежать від суми касових зборів);

(9) Чиказький Регіональний План (цей план подібний до Лос-Анджелеського «Плану на 99 місць», але діє в межах Чикаго);

(10) лист-згода (застосовується до невеликих театрів-початківців 3 обмеженими ресурсами і доходами, які в своїй діяльності потребують мінімальних щотижневих зарплат на суму 100 доларів кожна плюс пільги).
Наведений приклад контрактів повинен бути підгрунтям, на якому українські спеціалісти із театральної справи можуть розробити низку нормативних документів для регулювання взаємовідносин (взаємосодій) продюсерського центру та репертуарного театру. Фактично із появою у репертуарному театрі продюсерського центру виникає нове системне утворення, до емерджентних якостей котрого необхідно віднести здатність (компетенцію) ефективної праці неприбуткової організації (репертуарного театру) в ринкових умовах господарювання. При цьому ефективність доцільно визначати як вектор, складові якого наведено на рис. 6.

Завданнями

продюсерського центру будуть: (1) висока оперативність задоволення глядацьких вподобань, (2) висока результативність діяльності, (3) оптимальна ресурсомісткість за рахунок спрямованості на бюджетні театральні продукти.

До створення продюсерського центру є сенс підійти як до стартапу [17], який починає свою діяльність в умовах високої невизначеності та гострого дефіциту грошового забезпечення діяльності. При цьому його головним завданням буде трансформація творчих ідей $\mathrm{y}$ комерційні продукти при відповідній оцінці реакції споживачів (глядачів) і з висновками відносно вибору подальшого напряму розвитку творчовиробничих подій в системі «репертуарний театр / продюсерський центр». Зрозуміло, що для управління такою системою знадобиться відповідний менеджмент, який буде налаштований на постійні інновації, експерименти та безперервне навчання.

Цілком ймовірно, що стартап може бути заснований за рахунок фандрейзингу - комплексної технології сучасного менеджменту для залучення коштів на проекти та програми в сфері культури i освіти [18, С. 5]. 


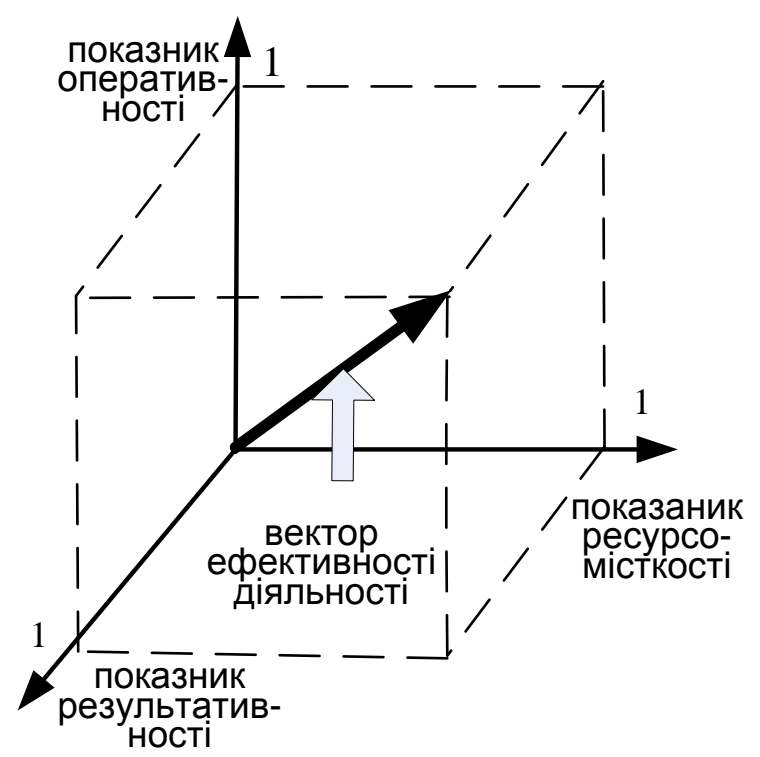

Рис. 6. Модель вектора ефективності господарської діяльності продюсерського центру [16, С. 216]

Висновки. Підсумовуючи вище викладене, можна дійти до тверджень: (1) стрімке скорочення бюджетної підтримки сучасних українських репертуарних театрів може завершитися повним відказом від неї; (2) за таких умов стане доцільним вивчення досвіду організації діяльності закордонних неприбуткових театрів, що достатньо успішно виживають за ринкових умов; (3) таке стає можливим завдяки використанню достатньо специфічної діяльності із назвою «продюсування»; (4) сучасним українським репертуарним театрам доведеться освоювати його; (5) 3 цією метою уявляється доцільним створення в театрі «продюсерського центру», який можна започаткувати як стартап; (6) завдяки цьому виникає нова творчовиробнича система, яка породжує попит на відповідний менеджмент, який буде налаштований на постійні інновації, експерименти та безперервне навчання.

\section{ПЕРЕЛІК ВИКОРИСТАНИХ ДЖЕРЕЛ}

1. Закон України «Про театри i театральну справу» (Відомості Верховної Ради (ВВР), 2005, № 26, ст.350)\{І змінами, внесеними згідно із Законами №
3421-IV від 09.02.2006, BВР, 2006, № 22, ст.199 N 5461-VI від 16.10.2012, ВВР, 2014, № 5, ст.62 № 406-VII від 04.07.2013, BВP, 2014, № 20-21, ст.712 № 911-VIII від 24.12.2015, ВBP, 2016, № 5, ст.50 № 955VIII від 28.01.2016, ВВР, 2016, № 10, ст.103\}

2. Сєріков А.В. Економіка та управління у сучасному українському репертуарному театрі: монографія. [Текст] / А.В. Сєріков, І.М. Коваль. - Харків: ФОП Панов А.М., 2018. - 314 с.

3. Langley S. Theatre management and production in America: principle and practice. [Text] / Stephen Langley.- New York: Drama book specialists publishers, 1990.- $680 \mathrm{p}$.

4. Самитов Д.Г. Продюсирование некоммерческого театра: История, социология, менеджмент, маркетинг, правовые аспекты региональных театров США. [Текст] / Д.Г. Самитов.- $\mathrm{M}$.: Российский институт театрального искусства - ГИТИС, 2016.- 559 с.

5. Закон України «Про державноприватне партнерство» (Відомості Верховної Ради (ВВР), 2010, № 40,ст.524)

6. Великий тлумачний словник сучасної української мови (з дод. і допов.) [Текст] / Уклад. і голов. ред. В.Т. Бусел. - 
К.; Ірпінь: ВТФ «Перун», 2005. - 1728 с.

7. Роднянский А.Е. Выходит продюсер. [Текст] / А.Е. Роднянский.- М.: Манн, Иванов и Фербер, 2013.- 288 с.

8. Управление проектом. Основы проектного управления: Учебник / кол. авторов; под. ред.. М.А. Разу.- М.: КНОРУС, 2006.- 768 с.

9. Шервуд Д. Системное мышление для руководителей: Практика решения бизнес-проблем. [Текст] / Деннис Шервуд; пер. с англ. - М.: Альпина Паблишер, 2016. $-300 \mathrm{c}$.

10. Яндовицкая Л.Г. Маркетинг в партере [Текст] / Л.Г. Яндовицкая // Маркетолог.- 2005.- №2.- с. 8-12.

11. Шерман С. Семь ключевых принципов управления ключевыми клиентами [Текст] / С. Шерман, Дж. Сперри, С. Риз; пер. с англ.- М.: ЗАО «Издательский Дом Гребенникова», 2005.$192 \mathrm{c}$.

12. Гордон Я. Маркетинг партнерских отношений: [Текст] / Ян Х. Гордон; пер. с англ. под. ред. О.А. Третьяк.- СПб.: Питер, 2001.- 384 с.

13. Егорова М.Н. Театральная публика. Эволюция анкетного метода: монография. [Текст] / М.Н. Егорова.- М.: ГИИ, 2010.- 162 с.

14. Аксютіна А.В. Продюсерська діяльність як предмет цивільно-правового договору у сфері інтелектуальної власності. [Текст] / А.В. Аксютіна // Митна справа. - 2014. - № 1(91). - С. 25 30.

15. Галацан Г.В. Американський неприбутковий театр: можливості застосування досвіду. [Текст] / Г.В. Галацан // Наукові записки Тернопільського національного педагогічного університету. - Серія: мистецтвознавство. - 2010. - № 1. - С. $142-148$.

16. Сериков А.В. Эффективность хозяйственной деятельности: определение, измерение, синергетическое управление. [Текст] / А.В. Сериков // Економічний вісник Донбасу.- 2011.- № 2(24).- С. 212 219.

17. Рис Э. Бизнес с нуля: Метод Lean Startup для быстрого тестирования идей и выбора бизнес-модели. [Текст] / Эрик Рис; пер. с англ.; 2-е изд. - М.: Альпина Паблишер, 2013.- 253 с.

18. Артемьева Т.В. Фандрейзинг: привлечение средств на проекты и программы в сфере культуры и образования: учебное пособие. [Текст] / Т.В. Артемьева, Г.Л. Тульчинский.- СПб.: Изд-во «Лань»; «Изд-во ПЛАНЕТА МУЗЫКИ», 2010. - 286 с.

DOI 10.18664/338.47:338.45.v\%vi\%i.145658 